\title{
Estimation of Heavy Metal Levels in the Muscle, Gizzard, Liver and Kidney of Broiler, Layer and Local (Cockerel) Chickens Raised within Awka Metropolis and Its Environs, Anambra State, South Eastern Nigeria
}

\author{
P. A. C. Okoye', V. I. E. Ajiwe', O. R. Okeke², I. I. Ujah'3, U. B. Asalu4, D. O. Okeke \\ ${ }^{1}$ Pure and Industrial Chemistry Department, Nnamdi Azikiwe Univeristy, Awka, Nigeria \\ ${ }^{2}$ Optical Section, Scientific Equipment Development Institute, Enugu, Nigeria \\ ${ }^{3}$ Department of Biochemistry, University of Nigeria, Nsukka, Nigeria \\ ${ }^{4}$ Plastic Section, Scientific Equipment Development Institute, Enugu, Nigeria \\ ${ }^{5}$ Department of Applied Biochemistry, Nnamdi Azikiwe University, Awka, Nigeria \\ Email: obinnaoje@yahoo.com
}

Received 11 April 2015; accepted 26 June 2015; published 30 June 2015

Copyright (C) 2015 by authors and Scientific Research Publishing Inc.

This work is licensed under the Creative Commons Attribution International License (CC BY).

http://creativecommons.org/licenses/by/4.0/

(c) (i) Open Access

\begin{abstract}
65 chickens (layer, broiler and cockerel) from different farms within Awka metropolis and its environs were purchased, processed and analyzed for the levels of heavy metals $\mathrm{(Pb}, \mathrm{As}, \mathrm{Cd}, \mathrm{Ni}, \mathrm{Cr}, \mathrm{Hg}$, $\mathrm{V}$ and $\mathrm{Cu}$ ) in the internal organs (muscle, gizzard, liver and kidney) of the chickens using flame atomic absorption spectrometer after nitric/perchloric acid digestion. The ranges of mean concentrations of the metals in the internal organs of the chickens in $\mathrm{mg} / \mathrm{g}$ were $\mathrm{Pb} ;(0.046$ - 0.478$) \mathrm{As}$; (0.053 - 0.318), Cd; (0.027 - 0.649), Cr; (0.045 - 0.234), Hg; (0.052 - 0.740), Ni; (0.038 - 0.534), V; (0.037 - 0.053), and $\mathrm{Cu}$; (0.146 - 0.445). About $10 \%$ - $40 \%$ of $\mathrm{Pb}, \mathrm{Cd}$ and $\mathrm{Hg}$ exceeded the permissible level of $0.5 \mathrm{ppm}$ set for these metals in the liver and kidney of the chickens. Anova analysis revealed significance of the heavy metals in the internal organs of the chickens at $p<0.05$.
\end{abstract}

\section{Keywords}

Heavy Metals, Bioaccumulation, Liver, Muscle, Gizzard, Kidney, Environmental Pollution 


\section{Introduction}

The poultry industry is one of the largest and fastest growing agro based industries in the world. This can be attributed to an increasing demand for poultry meat and egg products [1]. More than 50 billion chickens are raised annually as a source of food for both their meat and eggs. Chicken raised for eggs are usually called layers while chickens raised for meat are often called broilers [2]. A complete and balanced diet is necessary for the human health and vitality. Poultry meat is considered as a source of animal protein with high biological amino acids, many vitamins and minerals which are required for human nutrition beside its relative low price compared with red meat [3] [4].

Trace minerals have a very important role to play in the mechanism of nutrient circulation in the animal organs. The development of modern technology and the rapid industrialization are among the foremost factors of environmental pollution. Heavy metal pollution is posing a serious problem in Nigeria, threatening the animal and human health and quality of the environment [5].

The heavy metals of great concern are cadmium lead, mercury and arsenic which are usually associated with harmful effects in man and animals [5] [6]. Many heavy metals accumulate in one or more body organs with differing half-lives [7]. Food contamination with heavy metals is a serious threat because of their toxicity, bioaccumulation and bio-magnification in the food chain [8].

The main sources of metals in chicken meat arise from contamination of poultry feeds, drinking water and processing [9]. Toxic effects of the heavy metals to the chickens include feed refusal, loss of weight, low digestibility, organ failure and death while in higher animals it include, kidney and liver damage, anemia, alteration of central nervous system and cancer [10].

Demirezen et al. [8] revealed that the primary site of the accumulation of the heavy metals is the liver and the kidney. The study was conducted to estimate the levels of eight heavy metals in the internal organs of chickens raised within Awka metropolis and its environs.

\section{Materials and Methods}

Sample Collection: 65 live chicken samples (broilers, layers and local cockerel) were obtained from various farms within Awka metropolis and its environs. 260 meat samples comprising the liver, kidney, gizzard and muscle of the chickens were wrapped in polyethene bags and transported to the laboratory for analysis.

Sample Preparation: $2 \mathrm{~g}$ of each dried meat sample was weighed into a $100 \mathrm{ml}$ polythene bottle. $10 \mathrm{ml}$ of the digestion mixture $\left(3: 265 \% \mathrm{HNO}_{3}\right.$ and $\left.70 \% \mathrm{HClO}_{4}\right)$ were added. The bottles were tightly closed and the contents were gently swirled and allowed to stand overnight. The samples were heated for 3 hours in a water bath adjusted to $70^{\circ} \mathrm{C}$ with occasional swirling at 3 mins interval to ensure complete digestion of the samples. Finally, the digest was allowed to cool and then transferred into a $20 \mathrm{ml}$ standard flask. The solutions were transferred into acid leached poly-ethlene bottles and kept at room temperature until analysis with AAS.

Spectroscopic Analysis: The sample solutions were subsequently analyzed for heavy metal contents on wet weight basis using flame atomic absorption spectrometer. Measurements were made using the hollow cathode lamps for $\mathrm{Pb}, \mathrm{As}, \mathrm{Cd}, \mathrm{Cr}, \mathrm{Hg}, \mathrm{Ni}, \mathrm{V}$ and $\mathrm{Cu}$ at the proper wave length and other AAS conditions were employed in the determinations.

Quality Assurance: Appropriate quality assurance procedures and precautions were carried out to ensure reliability of the results. Samples were generally carefully handled to avoid contamination. Glassware was properly cleansed and the reagents were of analytical grade.

Reagents blank determinations were used to correct the instrument readings. A recovering study of the analytical procedure was carried out by spiking the kidney samples with $1 \mathrm{ppm}(\mathrm{Pb}, \mathrm{As}, \mathrm{Cd}, \mathrm{Cr})$ and $2 \mathrm{ppm}(\mathrm{Hg}, \mathrm{Ni}$, $\mathrm{V}, \mathrm{Cu}$ ). Triplicate analysis of the spiked samples and blank were carried through the digestion reaction. Average recoveries obtained were $99.73 \pm 2.177,103.1 \pm 7.87,100.17 \pm 2.02,100.0 \pm 2.95,93.83 \pm 11.25,99.13 \pm 0.808$, $95.4 \pm 5.803$ and $99.7 \pm 7.39$ for $\mathrm{Pb}$, As, $\mathrm{Cd}, \mathrm{Cr}, \mathrm{Hg}, \mathrm{Ni}, \mathrm{V}$ and $\mathrm{Cu}$ respectively.

\section{Result and Discussion}

The methodology used for the analysis was validated by the good triplicate recoveries obtained in Table 1.

The chicken types with different superscripts in the studied chicken parts have significantly different concentrations of heavy metals in the parts along the same column. 
Table 1. Result of the recovery for $\mathrm{Pb}, \mathrm{As}, \mathrm{Cd}, \mathrm{Cr}, \mathrm{Hg}, \mathrm{Ni}, \mathrm{V}$ and $\mathrm{Cu}$ in the kidney samples.

\begin{tabular}{|c|c|c|c|c|c|}
\hline Element & $\begin{array}{l}\text { Concentration of } \\
\text { metal added } \\
\text { (spiked) (mg/g) }\end{array}$ & $\begin{array}{l}\text { Concentration of metal } \\
\text { in the original sample } \\
\text { (unspiked) (mg/g) }\end{array}$ & $\begin{array}{l}\text { Concentration of } \\
\text { metal in the spiked } \\
\text { sample (mg/g) }\end{array}$ & $\begin{array}{c}\text { Recovered } \\
\text { concentrations } \\
(\mathbf{m g} / \mathrm{g})\end{array}$ & \% Recovery \\
\hline $\begin{array}{c}\mathrm{Pb} \\
\text { Mean } \pm \text { SD }\end{array}$ & $\begin{array}{l}1 \\
1 \\
1\end{array}$ & $\begin{array}{l}0.430 \\
0.432 \\
0.426\end{array}$ & $\begin{array}{l}1.428 \\
1.432 \\
1.420\end{array}$ & $\begin{array}{l}0.998 \\
1.000 \\
0.994\end{array}$ & $\begin{array}{c}99.8 \\
100 \\
99.4 \\
\mathbf{9 9 . 7 3} \pm \mathbf{2 . 1 7 7}\end{array}$ \\
\hline $\begin{array}{c}\text { As } \\
\text { Mean } \pm \text { SD }\end{array}$ & $\begin{array}{l}1 \\
1 \\
1\end{array}$ & $\begin{array}{l}0.331 \\
0.326 \\
0.329\end{array}$ & $\begin{array}{l}1.231 \\
1.216 \\
1.360\end{array}$ & $\begin{array}{l}0.900 \\
0.890 \\
1.031\end{array}$ & $\begin{array}{c}90 \\
89 \\
103.1 \\
\mathbf{1 0 3 . 1} \pm \mathbf{7 . 8 7}\end{array}$ \\
\hline $\begin{array}{c}\text { Cd } \\
\text { Mean } \pm \text { SD }\end{array}$ & $\begin{array}{l}1 \\
1 \\
1\end{array}$ & $\begin{array}{l}0.586 \\
0.604 \\
0.589\end{array}$ & $\begin{array}{l}1.591 \\
1.584 \\
1.609\end{array}$ & $\begin{array}{l}1.005 \\
0.980 \\
1.020\end{array}$ & $\begin{array}{c}100.5 \\
98 \\
102 \\
\mathbf{1 0 0 . 1 7} \pm \mathbf{2 . 0 2}\end{array}$ \\
\hline $\begin{array}{c}\mathrm{Cr} \\
\text { Mean } \pm \text { SD }\end{array}$ & $\begin{array}{l}1 \\
1 \\
1\end{array}$ & $\begin{array}{l}0.312 \\
0.309 \\
0.310\end{array}$ & $\begin{array}{l}1.312 \\
1.289 \\
1.348\end{array}$ & $\begin{array}{l}1.000 \\
0.980 \\
1.038\end{array}$ & $\begin{array}{c}100 \\
98 \\
103.8 \\
\mathbf{1 0 0 . 6} \pm \mathbf{2 . 9 5}\end{array}$ \\
\hline $\begin{array}{c}\mathrm{Hg} \\
\text { Mean } \pm \text { SD }\end{array}$ & $\begin{array}{l}2 \\
2 \\
2\end{array}$ & $\begin{array}{l}0.374 \\
0.403 \\
0.385\end{array}$ & $\begin{array}{l}2.174 \\
2.533 \\
2.085\end{array}$ & $\begin{array}{l}1.800 \\
2.130 \\
1.700\end{array}$ & $\begin{array}{c}90 \\
106.5 \\
85 \\
\mathbf{9 3 . 8 3} \pm \mathbf{1 1 . 2 5}\end{array}$ \\
\hline $\begin{array}{c}\mathrm{Ni} \\
\text { Mean } \pm \text { SD }\end{array}$ & $\begin{array}{l}2 \\
2 \\
2\end{array}$ & $\begin{array}{l}0.019 \\
0.015 \\
0.019\end{array}$ & $\begin{array}{l}2.019 \\
1.995 \\
1.986\end{array}$ & $\begin{array}{l}2.000 \\
1.980 \\
1.967\end{array}$ & $\begin{array}{c}100 \\
99 \\
98.4 \\
\mathbf{9 9 . 1 3} \pm \mathbf{0 . 8 0 8}\end{array}$ \\
\hline $\begin{array}{c}\mathrm{V} \\
\text { Mean } \pm \text { SD }\end{array}$ & $\begin{array}{l}2 \\
2 \\
2\end{array}$ & $\begin{array}{l}0.063 \\
0.057 \\
0.069\end{array}$ & $\begin{array}{l}1.967 \\
1.850 \\
2.094\end{array}$ & $\begin{array}{l}1.904 \\
1.793 \\
2.025\end{array}$ & $\begin{array}{c}95.20 \\
89.65 \\
101.25 \\
\mathbf{9 5 . 4} \pm \mathbf{5 . 8 0 3}\end{array}$ \\
\hline $\begin{array}{c}\mathrm{Cu} \\
\text { Mean } \pm \text { SD }\end{array}$ & $\begin{array}{l}2 \\
2 \\
2\end{array}$ & $\begin{array}{l}0.134 \\
0.133 \\
0.130\end{array}$ & $\begin{array}{l}2.185 \\
1.958 \\
2.234\end{array}$ & $\begin{array}{l}2.051 \\
1.825 \\
2.104\end{array}$ & $\begin{array}{c}102.55 \\
91.25 \\
105.20 \\
\mathbf{9 9 . 7} \pm \mathbf{7 . 3 9}\end{array}$ \\
\hline
\end{tabular}

Table 2 showed that the range of the mean concentrations of the heavy metals in the internal organs of the layer chickens in mg/g were Pb; (0.046 - 0458), As; (0.082 - 0.196), Cd; (0.027 - 0.608), Cr; (0.083 - 0.143), Hg, (0.053 - 0.541), Ni; (0.208 - 0.339), and Cu; $(0.137-0.314)$. The order of the metal increase in the internal organs were; $\mathrm{Cd}>\mathrm{Hg}>\mathrm{Pb}>\mathrm{Ni}>\mathrm{Cu}>\mathrm{As}>\mathrm{Cr}$.

For the broiler chickens, the range of the mean concentrations of the heavy metals in the internal organs in mg/g were Pb; (0.036 - 0.370), As; (0.053 - 0.119), Cd; (0.030 - 4.93), Cr; (0.040 - 0.104), Hg; (0.052 - 0.508), $\mathrm{Ni} ;(0.038-0.145)$ and $\mathrm{Cu} ;(0.155-0.445)$. The order of the metals increase in the internal organs were $\mathrm{Hg}>$ $\mathrm{Cd}>\mathrm{Cu}>\mathrm{Pb}>\mathrm{As}>\mathrm{Ni}>\mathrm{Cr}$.

For the local chickens, the range of the mean concentrations of the heavy metals in the internal organs in $\mathrm{mg} / \mathrm{g}$ were Pb; (0.058 - 0.003), As; (0.140 - 0.318), Cd; (0.058 - 6.49), Cr; (0.193 - 0.234), Hg; (0.071 - 0.740), Ni $(0.122-0.534), \mathrm{V} ;(0.037-0.053)$ and $\mathrm{Cu} ;(0.218-0.314)$. The order of the metals increase in the internal organs were $\mathrm{Hg}>\mathrm{Cd}>\mathrm{Pb}>\mathrm{Ni}>\mathrm{As}>\mathrm{Cu}>\mathrm{Cr}>\mathrm{V}$.

For the three chicken type analyzed, the heavy metal accumulation in their internal organs decreased as follows; local chicken cockerel > layer chicken > broiler chicken. The reason for these observations were confirmed by Neisham et al. [11] who noted that free range local chickens usually harbor the greatest pollutants in their body system as they have no oral discrimination hence pick whatever they find edible in the environment. Layer chickens harbored higher heavy metals loads than broiler chickens probably because of age difference of chickens and length of exposure to metals through their feeds etc.

In all the three chicken types, $\mathrm{Pb}, \mathrm{Cd}, \mathrm{Hg}$ and As were of the highest concentrations compared to other studied 
Table 2. Mean concentration of the heavy metals in the internal organs of the chickens.

\begin{tabular}{|c|c|c|c|c|c|c|c|c|c|}
\hline $\begin{array}{c}\text { Sample } \\
\text { Type }\end{array}$ & Parts & $\mathbf{P b}$ & As & Cd & $\mathrm{Cr}$ & Hg & $\mathbf{N i}$ & $\mathbf{V}$ & $\mathbf{C u}$ \\
\hline \multirow{4}{*}{ Layer } & Muscle & $0.046 \pm 0.005^{\mathrm{a}}$ & $0.082 \pm 0.019^{\mathrm{a}}$ & $0.027 \pm 0.006^{\mathrm{a}}$ & $0.127 \pm 0.062$ & $0.053 \pm 0.013^{\mathrm{a}}$ & $0.339 \pm 0.032^{\mathrm{a}}$ & - & $0.196 \pm 0.026^{\mathrm{a}}$ \\
\hline & Gizzard & $0.185 \pm 0.024^{b}$ & $0.196 \pm 0.058^{\mathrm{b}}$ & $0.156 \pm 0.019^{b}$ & $0.143 \pm 0.081$ & $0.183 \pm 0.047^{b}$ & $0.325 \pm 0.052^{\mathrm{a}}$ & - & $0.236 \pm 0.018$ \\
\hline & Liver & $0.441 \pm 0.099^{c}$ & $0.178 \pm 0.038^{c}$ & $0.608 \pm 0.108^{c}$ & $0.083 \pm 0.031$ & $0.520 \pm 0.049^{c}$ & $0.205 \pm 0.061^{\mathrm{b}}$ & - & $0.146 \pm 0.014^{\mathrm{a}}$ \\
\hline & Kidney & $0.458 \pm 0.090^{\mathrm{d}}$ & $0.188 \pm 0.026^{d}$ & $0.522 \pm 0.029^{c}$ & $0.111 \pm 0.039$ & $0.541 \pm 0.074$ & $0.228 \pm 0.065^{\mathrm{b}}$ & - & $0.137 \pm 0.011^{\mathrm{a}}$ \\
\hline \multirow{4}{*}{ Broiler } & Muscle & $0.036 \pm 0.012^{\mathrm{a}}$ & $0.053 \pm 0.014^{\mathrm{a}}$ & $0.030 \pm 0.008^{\mathrm{a}}$ & $0.054 \pm 0.019$ & $0.052 \pm 0.007^{\mathrm{a}}$ & $0.121 \pm 0.019^{\mathrm{a}}$ & - & $0.155 \pm 0.007$ \\
\hline & Gizzard & $0.112 \pm 0.019^{b}$ & $0.118 \pm 0.018^{\mathrm{b}}$ & $0.131 \pm 0.032^{\mathrm{b}}$ & $0.104 \pm 0.012$ & $0.136 \pm 0.012^{\mathrm{b}}$ & $0.139 \pm 0.022^{\mathrm{a}}$ & - & $0.445 \pm 0.027$ \\
\hline & Liver & $0.370 \pm 0.012^{c}$ & $0.132 \pm 0.080^{c}$ & $0.493 \pm 0.083^{c}$ & $0.045 \pm 0.016$ & $0.508 \pm 0.054$ & $0.038 \pm 0.008$ & - & $0.223 \pm 0.022$ \\
\hline & Kidney & $0.243 \pm 0.035^{\mathrm{d}}$ & $0.119 \pm 0.031^{d}$ & $0.343 \pm 0.015^{\mathrm{d}}$ & $0.040 \pm 0.008$ & $0.343 \pm 0.091^{\mathrm{d}}$ & $0.145 \pm 0.026^{\mathrm{a}}$ & - & $0.172 \pm 0.042$ \\
\hline \multirow{4}{*}{$\begin{array}{l}\text { Local } \\
\text { Chicken } \\
\text { (Cockerel) }\end{array}$} & Muscle & $0.058 \pm 0.013^{\mathrm{a}}$ & $0.140 \pm 0.012^{\mathrm{a}}$ & $0.058 \pm 0.017^{\mathrm{a}}$ & $0.193 \pm 0.011^{\mathrm{a}}$ & $0.071 \pm 0.014^{\mathrm{a}}$ & $0.130 \pm 0.022^{\mathrm{a}}$ & $0.037 \pm 0.007$ & $0.276 \pm 0.037$ \\
\hline & Gizzard & $0.207 \pm 0.047^{\mathrm{b}}$ & $0.318 \pm 0.071^{\mathrm{b}}$ & $0.243 \pm 0.039^{\mathrm{b}}$ & $0.234 \pm 0.047^{\mathrm{a}}$ & $0.207 \pm 0.036^{\mathrm{b}}$ & $0.534 \pm 0.078^{\mathrm{b}}$ & $0.040 \pm 0.014$ & $0.259 \pm 0.091$ \\
\hline & Liver & $0.503 \pm 0.085^{c}$ & $0.233 \pm 0.025^{c}$ & $0.649 \pm 0.101^{\mathrm{c}}$ & $0.233 \pm 0.013^{\mathrm{a}}$ & $0.740 \pm 0.091^{\mathrm{c}}$ & $0.174 \pm 0.059^{\mathrm{a}}$ & $0.042 \pm 0.011$ & $0.218 \pm 0.041$ \\
\hline & Kidney & $0.478 \pm 0.070^{\mathrm{d}}$ & $0.196 \pm 0.015^{\mathrm{d}}$ & $0.578 \pm 0.033^{d}$ & $0.196 \pm 0.037^{\mathrm{b}}$ & $0.578 \pm 0.075^{d}$ & $0.122 \pm 0.042^{\mathrm{a}}$ & $0.053 \pm 0.013$ & $0.314 \pm 0.088$ \\
\hline
\end{tabular}

metals in the liver and kidney showing that they are not easily metabolized and bio accumulates in these two above mentioned principal organs [8]. Anova analysis revealed significance of the heavy metals in the internal organs of the chickens at $\mathrm{p}<0.05$. The anova analysis showed that because the internal organs analyzed performed specific functions, they accumulate heavy metals differently. The order of accumulation of heavy metals in the internal organs of the chickens were liver $>$ kidney $>$ gizzard $>$ muscle.

Nesheim, et al, [11] noted that the liver is the site where metabolism occurs; the kidney performs the function of excretion; the gizzard is used for disintegration of the absorbed food particles while the muscle has no known metabolic function.

The high levels of $\mathrm{Pb}, \mathrm{Cd}, \mathrm{Hg}$ and As in the internal organs of the chickens could have come from of anthropogenic activities in the environment, feeds and water fed to the chickens. The heavy metals were within the established permissible levels in the internal organs of the chickens with the exception of $\mathrm{Hg}, \mathrm{Pb}$ and $\mathrm{Cd}$ on few occasions [12]. The results obtained in this study were lower than Pb; $(7.76 \pm 0.03) \mathrm{mg} / \mathrm{g}, \mathrm{Cd}$; (1.39 \pm 0.09$)$ $\mathrm{mg} / \mathrm{g}$, and $\mathrm{Cu} ;(2.30 \pm 0.08) \mathrm{mg} / \mathrm{g}$ reported for these metals in chickens raised in Algeria [13]. Hiba, [14] obtained similar results for lead in the muscle, liver and gizzard of slaughtered cattle in Mosul, Egypt. The Pb values he obtained in the muscle, liver and gizzard were $0.071,0.472$ and $0.398 \mathrm{mg} / \mathrm{kg}$ respectively.

Iwegbue, et al., [15] also reported values of $0.46 \pm 0.58 \mathrm{mg} / \mathrm{kg}$ for $\mathrm{Cu}, 0.33 \pm 0.14 \mathrm{mg} / \mathrm{kg}$ for $\mathrm{Cr} ; 0.37 \pm 0.15$ $\mathrm{mg} / \mathrm{kg}$ for $\mathrm{Cd}$ and $0.77 \pm 0.01 \mathrm{mg} / \mathrm{kg}$ for $\mathrm{Pb}$ in Chicken meat consumed in southern Nigeria similar to the obtained for these metals in this study.

\section{Conclusions}

From the results of this study, the concentrations of the heavy metals in the kidney, liver, gizzard and muscle of the chickens were found to be statistically significant at $p<0.05$. The specific functions performed by these organs and the non-metabolic nature of the heavy metals in the system were reasons adduced for the obvious significance.

Generally, the liver, kidney and gizzard of all the samples were found to have significant levels of metals than in the muscle.

The concentration of all the metals was within established permissible limits with the exception of $\mathrm{Pb}, \mathrm{Hg}$ and Cd on few occasions in the liver and kidney. Consumption of chicken meats by the inhabitants of Awka and its environs will not result to heavy metal toxicity, however, anthropogenic factors that proliferate heavy metals in the environment should be discontinued and discouraged. 


\section{References}

[1] Burel, S.A. and Valat, C. (2009) The Effect of the Feed on the Host Microflora Interactions in Poultry: An Overview. Proceedings in International Symposium in Sustainable Animal Production-The Challenges and Potential Developments for Professional Farming for 13th Congress of the International Society for Animal Hygiene, 72, 645-652.

[2] Appleby, M.C., Merich, J.A. and Hoghes, B.O. (2004) Poultry Behavior and Welfare. CABI Publishing, Walling Ford and Cambrige MA, 176.

[3] Institute of Medicine (2001) Dietary Reference Intakes for Vitamin A, Vitamin K, Arsenic, Boron, Chromium, Copper, Iodine, Iron, Managanese, Molybdenum, Nickel, Silicon, Vanadium and Zinc. Washington DC, 733-736.

[4] Collins, D. and Gracey, J. (1992) Meat Hygiene. 9th Edition, Bailliere Tundall Press, London, 219.

[5] Dekofehiniti, O.O., Omotoyi, I.O., Oloremu, A.G. and Abayomi, T.G. (2012) Heavy Metals Distribution and Lipid Profile in the Stomach of Cow Grazed in Akugbe-Akoko, Ondo State Nigeria. African Journal of Biochemistry Research, 6, 146-149.

[6] Piska, R.S., Swamy, P.U. and Parvalli, R. (2004) Heavy Metal Pollution and Its Toxic Effect on Ground Water Quality of Jeedometa, India. Journal of Environmental Science Health, 34, 91-102.

[7] Teresa, M., Vosconcelos, S.D. and Tavares, H.M. (1997) Trace Elements Concentration in Blood and Hair of Young Apprentices of a Technical Professional School. Science of the Total Environment, 205, 189-199. http://dx.doi.org/10.1016/S0048-9697(97)00208-8

[8] Demirezen, O. and Uruc, K. (2006) Comparative Study of Trace Elements in Certain Fish, Meat and Meat Products. Food Chemistry, 32, 215-222. http://dx.doi.org/10.1016/j.meatsci.2006.03.012

[9] Mariam, I.S. and Nagre, S. (2004) Distribution of Some Trace and Macro Minerals in Beef, Mutton and Poultry. International Journal of Agric and Biology, 6, 816-820.

[10] Hassan, A.R., Saleh, M., Sobih, M., Wilson, S. and Reddy, P. (1998) Effects of Some Heavy Metals Pollutants on the Performance and Immune System of Chicks. Poultry Science, 77, 24-30.

[11] Nesheim, M.C., Austic, R.E. and Cand, L. (1979) Poultry Production. 12th Edition, Lea and Febiger, Philadelphia, 123-125.

[12] FAO/WHO (2006) Report of the 32nd Session of the Codex Committee of the Food Additives and Contaminants. Beijing.

[13] Bendeddouche, B., Zellagvi, R. and Bendeddooche, E. (2004) Levels of Selected Heavy Metals in Fresh Meat from Cattle, Sheep, Chicken and Camel Produced in Algeria. Annual Research and Review and Biology, 4, 1260-125.

[14] Hiba, S.A. (2011) Estimation of Lead and Cadmium Levels in Muscles, Livers and Kidneys of Slaughtered Cattle in Mosul City, Egypt. Journal of Animal Science, 39, 8-16.

[15] Iwegbue, C.M.A., Nwojei, G.E. and Iyoha, E.H. (2008) Heavy Metal Residues of Chicken Meat, Gizzard and Turkey Meat Consumed in Southern Nigeria. Bulgarian Journal of Veterinary Medicine, 11, 275-280. 